\title{
Applications of Communicative Language Teaching Techniques in Reading Classes: A Special Focus on Junior Colleges in Telangana Region (India)
}

\author{
Manjulatha Devi Gudepu ${ }^{1, *}$ \\ ${ }^{1}$ Departement of English Kakatiya Institute of Technology and Science, Warangal, Andhra Pradesh, India \\ *Correspondence: Kakatiya Institute of Technology and Science, Warangal, Andhra Pradesh, India \\ Tel: 994-960-5716. E-mail: gmanjulatha@gmail.com
}

Received: April 5, 2013

Accepted: May 8, $2013 \quad$ Online Published: June 23, 2013

doi:10.5430/wjel.v3n2p57

URL: http://dx.doi.org/10.5430/wjel.v3n2p57

\begin{abstract}
Having worked in several Junior Colleges for many years and taught the students of both First and Second Year of Intermediate, the researcher was motivated to investigate into the perilous problems of both pedagogues and learners in teaching and learning, in order to discover judicious remedies for their irradiation. A prime focus on learners and teaching methods have provided an understanding to the researcher that too much interference of regional language, lack of reading habits and total absence of learning activities are the major causes for the poor communicative ability of students. The researcher's experiments with students of different learning capacities and the presentation of data analysis in the paper confirm the adaptability of communicative approach in reading classes. The paper accentuates the need for promoting learning ambience in English classrooms through compulsory participation of every student in various modes of interactions. It also offers an explanation regarding the role of teachers and students in communicative classes. Focusing on language acquisition through communicative approach the author proceeds to highlight the effectiveness of the approach and suggests reforms in reading activities in English class. In conclusion, the paper asserts that communicative ability is strengthened through reading and judicious implementation of teaching strategies will be successful in training and guiding the students to acquire sound communicative ability.
\end{abstract}

Keywords: communicative competence; reading activities; regional language dominance

\section{Introduction}

A desire to world exposure has successfully orientated the interest of students to learning of English for communication purpose. It is for this reason; the mode of teaching of English has conspicuously changed from Traditional Method of explaining to Communicative Method of involving. Of course, this does not mean that Traditional Method of teaching the language in schools, colleges and even in universities has altogether vanished. There is still strict adherence to Traditional Method of explaining the text to students in order to prepare them for examinations. Language teaching done in this way is too ineffective to help the students use it in real life situations and is sure to end up with a farewell to reading. Cliffor H. Pator (1965) points out: : "On the theoretical level, it would be easy to convince ourselves that communication is an essential component of language, that language bereft of its communicative functions is not language at all, but mere parroting." To test the communication ability of students, the researcher organized group discussions in a few Junior colleges on topics like ENVIRONMENTAL POLLUTION, DEMOCRACY AND INDIVIDUAL'S ROLE and ETHICAL USE OF TECHNOLOGY. The students were found unwilling to participate in the activity. When asked, they disclosed that they were bereft of ideas to speak about the topics given. This brought realization to the researcher that except text books, students never bothered to read any newspapers or novels or story books. The deficiency of knowledge, which is the consequence of complete elimination of reading, is detrimental to any progress. Lack of reading badly affects the thinking faculty of individuals and this leads to stagnation of knowledge. The researcher's determination to prove that reading opens gates to wisdom and communicative approach in reading classes would provide an easy access to learning became the basis of this research work. The paper emphasizes the need for inserting 'Reading Classes' in regular timetable and train students to become autonomous learners. The paper highlights that reading is the foundation for efficient communication. The students are 
elated to participate in any communicative activity when they possess the knowledge of current and past issues. Brown states, "Before you read, spend some time introducing a topic, encouraging skimming, scanning, and activating schema. Students can bring the best of their knowledge and skills to a text when they have been given a chance to 'ease' into the message."According to Carnegie (1962), "Reading is the subject to be learned by children; a child will learn little else in today's world if he does not first learn to read properly."

The other significant thing that fell in the notice of the researcher was undue focus on grammar teaching in colleges. This conscious teaching of grammar and giving grammar exercises for practice would produce positive results in examinations but cannot promote communicative ability among students. According to $\mathrm{Hu}$ (2002) this traditional grammar-translation method "failed to develop an adequate level of communicative competence (i.e. the ability to use the target language for authentic communication)" The Traditional Method of grammar teaching will permanently close the doors of learning in a student. Steinberg and Horwitz state : (1986: cited MacIntyre and Gardner, (1991:296) "Grammar is a set of rules which the learner not only has a tough time to learn but also an enervating activity of remembering and retrieving them." Language fluency is not merely because of grammar awareness. Eminent grammarians may not be adept users of language. Krashen (1987) states, “...that we should present rules at one time in one order when the goal is conscious learning." He stipulates that grammar teaching as knowledge is a kind that cannot be passed on with rules, but can only be acquired unconsciously through exposure to the language.(Krashen 1988). The institutions consist of instructors who possess deft command over language but, nonetheless, they need hands on training in teaching a language because teaching a language is different from being able to speak or write it. Having performed various tasks as a part of research; like interacting with teachers and students, observing teaching strategies, and testing modes, the researcher arrived to a conclusion that communicative approach in teaching would produce effective results in teaching-learning process.

The research lasted for eight months from July 2012 to Febraury 2013. Ten colleges at plus two level were chosen in Telangana Region of Andhra Pradesh state in India which followed state syllabus. As a part of research, the background of the students, suitability of the teachers to teach at college level, usefulness of the syllabus, experiments through implementation of reading in classrooms, and the advantages of them were mainly focused. The purpose of the research is to find out the outcomes of communicative approach in reading at college level.

\section{The Basis of the Study}

Teaching is not restricted to any single method. Keeping in view of the growing needs of students, new teaching strategies, techniques and methods are being invented and implemented to help the students acquire language skills. Every new strategy consists of better advantages than the previous one. A study of these methodologies provides an understanding that no teaching method is self-sufficient. But there is a possibility of effective learning when students experiment with what they are learning from instruction and discover from exposure to the examples that are provided by the teachers. According to Snow (1996), "Students learn effectively about language when they take part actively in communication with language rather than passively accepting what the teacher said. It is only through such experimentation that students become able users of a language." Hence the responsibility of the instructor is to foster a practice-based study environment with orientation towards "more participatory experimental techniques" (Knowles 1970,p.45). According to Littlewood,(1981) many aspects of language will take place only through natural process, which operate when a person is involved in using the language for communication. Ellis (1997) says, "Whether the learner is a good or a poor one depends largely on his/her understanding of the language, when learners are given a chance to make the full use of the limited time in classes to communicate overall language competence by communicating their text material in class which is largely reading material." According to Krashen (1983) -'adults have two distinctive ways of developing competences in second languages.... Acquisition that is by using language for real communication...... knowing about language'

The main objective of the research is to develop communicative competence among students. Students are to be trained in such a way that they are successful in expressing themselves in appropriate language. The language pedagogues should pay painstaking attention to activity-based learning and motivate the students to participate in classroom activities for practical application of their knowledge in daily interactions. Widdowson (1978) relates that we should teach language as communication and not as a stock of usage, which may never be realized in actual use at all. He continues to state "An overemphasis on drills and exercises for the production and reception of sentences tends to inhibit the development of communicative abilities (1978:67)." But in learning centers most of the time Traditional Method is implemented by instructors due to time constrain and population of the class. The researcher has realized that the process of learning becomes slow when the teacher is a focal point and learners are dumb listeners. 
Any approach will be effective when the learners are involved in learning programme. The research is intended to study the reading materials of students to decide the implementation of appropriate reading strategy to strengthen their communicative ability. Top-down and bottom-up methods are applied in reading. The students apply bottom-up strategy to identify a word, its structure with reference to spelling, and its pronunciation. Through reading students try to obtain information, and while reading they are mentally busy with recollections of their experiences, and perceptions, which show their resemblance with the issues the author has discussed in the text. They later communicate what they have read by participating in post-reading activities like critical thinking questions, group discussions, and analytical aptitude. The research is designed to persuade the students that the activity of learning is joyful and proffers full enjoyment to them when they take full responsibility for their success or failure in handling the language (Brow, 1991).

\section{Hypothesis}

Three hypotheses were proposed in the beginning of the study

1) Through communicative approach in reading there is a wider scope for students to strengthen their vocabulary by themselves than when it is done by a teacher independently.

2) Communicative approach through group discussions, debates, and individual presentations based on the reading material will help students use grammar in correct form in their language. It is to say that unconscious learning of grammar through communicative approach in reading is possible.

3) Communicative approach will be successful in orientating the interest of students to learning of English.

\section{Methodology}

During the first month of the study, the researcher interacted with teachers and students of the selected Junior Colleges. The interaction was done through questionnaires supplied to teachers and students in which the researcher solicited responses regarding the reading habits, methods, and strategies and their impressions about practicing reading at college. The opinions of nearly two hundred students including Senior and Junior Intermediate were taken and the data manifested that $90 \%$ of the teachers and students were found in favour of communicative approach in reading while $10 \%$ were reluctant to adopt this strategy. The researcher inferred that communicative strategy could be applied in reading to improve the students' language ability.

The questionnaire consisted of the following questions:

1) To Teachers

- How do you improve reading skills among students?

- How do you identify students who have reading difficulties?

- What type of exercises do you prefer to give to test the comprehension of students?

- Do you encourage your students to read novels to improve their reading ability?

- What do you feel about the role of vocabulary in reading comprehension?

- How do you give grammar knowledge to students?

- What strategies do you apply to make your students independent readers?

- Do you want to have Extensive Reading Programme in your college?

- Do you agree that loud reading would improve the pronunciation of students?

- How would you encourage the students to participate in activities?

2) To Students

- Do you love to read and understand the lesson yourself?

- Do you believe mere explanation of the text will help the students improve language skills?

- Are you ready to share your feelings with your classmates regarding your study material?

- What do feel about listening to a teacher silently for 50 minutes?

- What type of teaching do you expect for your active learning?

With the application of Traditional Method of teaching a language, students are accustomed to listening rather than 
participating. Most of the time they anticipate help from teacher in facilitating the complexity of the text instead of thinking and discussing. Pino-Sila (1992) advises teachers to explain their students the merits and importance of reading for pleasure in a foreign language, since it not only improves the readers' vocabulary and structure of the language, but also gives them a feeling of satisfaction to be able to read text in a foreign language. Teachers do not show much inclination to promoting reading sessions in institutions because they will not be able to complete the syllabus if they encourage this self-learning process. In such a situation, it was really a challenging task for the researcher to motivate the students to acquire self-learning skill through reading. The Primary objective of the research at this juncture was to invite the attention of students to reading and explain to them the advantages of it. The procedure of the research was done based on the following.

- Selection of the participants ( randam selection of nearly 200 participants from Junior and

- $\quad$ Senior Intermediate)

- Teaching Methods experimented (Traditional \& Communicative)

- Selection of the Reading Materials (I- R.K. Narayan's Astrologer's Day, A Snake in the Grass, Next Sunday. II-A.G. Gardiner's Essays- All about A Dog, On Saying Please, III-LIVER (Adopted from Richard Selzer Best Science Writing: Reading and Insights)

- Frequency of the sessions ( Every week three session, each session consisting of 50 minutes)

- Activities conducted ( Loud reading for pronunciation check, silent reading for identifying grammar components, vocabulary, coherence, strengths and weaknesses of the reading material. Students were asked to predict, judge and analyze various issues in the reading material to test their improvement in two areas: one comprehension and another in communicative ability)

- Grouping (Students were divided into small groups, each group consisted of minimum five students)

The students were given simple tasks related to vocabulary, grammar, and comprehension questions to generate confidence in them that they can learn and improve language skills through attentive reading and critical thinking. In the beginning, there was no time restraint to perform the tasks but later instructions were given to complete the given tasks in given time. This helped the students accelerate their thinking and responding quickly. By asking questions and extracting answers, the students were encouraged to comprehend the text by themselves. This kind of learner-centered teaching produced efficacious results because students were thrilled to realize the potential in them and in addition to that, they manifested enthusiasm to participate to be highlighted before their classmates.

\section{Sample Passage Prepared by the Researcher}

\section{MY FAMILY}

It gives me an immense pleasure to tell you about my family. After seeing my family members you will realize that my description of each of them is bang on. My father, being the head of the family has always been a latter day Hitler and my mother is no less than the step ford wives in the scriptures. Either of my parents has determination to keep their designation in our family. We, the eccentric children born to such parents, have not inherited the dictatorship of my father or the submissive nature of my mother. Each of my siblings loves identification as special individuals.

\subsection{Objective}

To help the students learn how to use 'each and either' appropriately.

\subsection{Procedure}

- Students were asked to go through the passage carefully

- They were asked to identify the sentences where 'each and either' are used and the nouns and verbs used with them

- They were asked if they knew any other words of same type like 'each or either' (using the term adjective while referring to 'each or every' was avoided to reduce the confusion of students. The researcher helped them in this task)

- Students were made to understand that singular verbs are used with each of, either of, neither of, none of with the examples in the passage. 
- $\quad$ Exercises were given to test their understanding

The Following Tasks Were Given To Students after Reading

Fill in the blanks choosing appropriate word in bracket

- Each of my (brother/brothers) (own/owns) a car.

- Neither of your ........ (statement/statements)........ (is/are) wise.

- None of the............(workers/worker)....... (has/have) children.

- $\quad$ Either the manager or the clerk........ (are/is) is to be available at the office.

\section{Correct the following sentences}

- $\quad$ Every man and every woman were encouraged to participate in freedom struggle.

- $\quad$ Either of these rooms seem spacious.

- $\quad$ Each of the boy have brought their books.

- None of my cousins live in Canada.

Majority of the students did the exercises correctly. They were happy to realize that learning grammar was easier through conscious reading than listening to grammar teaching.

\section{Second Survey}

It was designed to find out the difficulties of the students in reading. 15 percentage of the students expressed that they had a problem with different forms of words and their usage in communication. These students studied in schools situated in their villages and were taught by the teachers who were not trained to teach English. $25 \%$ of the students could efficiently use the language as they studied in public schools but they were void of comprehensive ability.

\section{Classroom Performances}

The researcher analyzed the problems and decided to plan classroom activities to enhance the reading ability of students. The researcher planned communicative activity of reading in three steps.

\section{Warm-up activity}

Before the students started reading, they were divided into groups or made into pairs to make sure that everyone was participating in the activity. The knowledge stored in their schema was put to use to find out the unknown knowledge through these activities. Group discussions, debates, picture or map illustrations, error identification, demonstrations, individual or group presentations, descriptions, assumptions, predictions, writer's intentions regarding several issues in his /her writing were organized to help the students open their minds and help one other in new acquisition of knowledge.

On several occasions it happens that students feel free to share their feelings with their friends. They feel free to give vent to their doubts to their peers. When the teacher encourages negotiations and discussions among the students the objective of teaching will be achieved because this encouragement provides an access to students to enjoy a very joyful share of knowledge. John Dewey's (1916) inquiry-based philosophy of education conceptualized the learning as: “As a shared activity in which the teacher is a learner and the learner is, without knowing it, a teacher." There is no scope for any chagrin to the educators when they detect the root cause for the animosity of student community for learning, which is a consequence of students' nil participation and teachers' total participation. According to Rao (2002) teachers may help their students understand the nature of language, the features of CLT, the functions of the class, the role of the student and teacher. Students' involvement in activities will fetch two fruitful results: one is good rapport is developed between the teacher and the taught: another is; the rate of learning carries momentum.

The researcher took sufficient care in providing congenial ambience to learning in the classroom. Students had leeway to move freely within the classroom to interact with their peers as long as the activity lasted. The activity was done with a great spirit and enthusiasm. As against the atmosphere of the classroom where students sit with lassitude, this classroom was chirpy with the active participation of every student; each trying to express something related to the activity and getting rewards of appreciation in return.

The activity was planned by making the students into groups. While one group framed questions, another group answered. The third group judged the correctness and the forth group negotiated regarding the judgment. Finally the teacher had to give opinion about the acceptability or unacceptability of the students' conclusions. Students felt extremely happy to be generators, predictors, facilitators, and judges. The researcher also found the teacher hilarious in 
interacting with students and helping them discover solutions.

\section{Reading Activities}

Students were asked to read the material. They were instructed to go through the material very meticulously to comprehend the global structure and gist of the reading text. The researcher elucidated the technique the students had to adopt while reading the material. The activity was conducted with an intention of promoting critical thinking among students, which included ability to discuss, narrate, negotiate, describe, elaborate, judge and conclude. Besides improving these abilities there was an equal emphasis on grammar and vocabulary. As far as the vocabulary teaching is concerned, the researcher followed an interesting procedure.

The researcher divided students into several groups.

- Students in each group had to go through the reading material, discuss with one another and finally prepare two lists: a list of unfamiliar words, and a list of known words. (Duration of time for this activity was 10 minutes)

- A student from each group stood up and read out the lists while other groups checked.(Duration of time for this activity was 5 minutes)

- In third stage, a student from each group had to explain the meaning of the word his/her group knew to other groups by using it in a simple sentence. This helped each other in guessing the meaning through context. (If the students made grammatical errors, either the researcher or the teacher helped them. Students did this activity in 20 minutes).

Every student had involvement in this activity. They learned how to derive the meanings from usage. Finally the teacher or the researcher helped them understand the remaining vocabulary: some by giving the meanings directly and some by providing examples which helped them predict the meanings. The students enjoyed this activity very much. They felt proud to have played the role of their teacher to give exercises to their friends to teach vocabulary. The activity produced amazing outputs.

\section{Predictive Reading Activity}

This activity was done to improve comprehension. Students were divided into groups. They were given handouts of the reading material. The task was; they had to read the passage in limited time and later discuss with their teammates to arrive to a conclusion. Afterwards the leader of one team read out their conclusion and mentioned their reasons for their predictions. All other teams listened to them and compared them with their predictions. If they found their predictions different, they pointed out with cogent arguments. This was how the whole class was involved in the activity. At the end, everybody had a feeling that they had new enlightenment. They stated that they learned to analyze the problem from different angles.

\section{Jigsaw Reading Activity}

A. Students were given a paragraph of a reading material. They had to read that paragraph and predict the previous and following of the paragraph. They did this activity in groups. After some time one person from one group read out the main ideas of the paragraph and other groups noted them. Likewise all groups prepared main ideas and predictions. At the end they encapsulated their points for global understanding.

B. Students were divided into groups. This was done by taking one student from each of the existing groups. The new groups consisted of the students who were earlier in other groups. Students were amused with the change and worked happily with new friends. They discussed their points with their teammates and arranged them in logical order maintaining coherence among sentences. Later one student from a group read out their performance to other groups. If any group had contrast opinions they felt free to express.

\section{Follow-Up Activity}

After these reading activities teachers asked questions to students to get their feedback. Group discussions and personal interviews were conducted in order to confirm that all students actually participated in the activities using language to improve their communication in English.

\section{Outcomes of the Study}

The following outcomes reveal the best advantages and benefits of implementing communicative approach.

After dealing with students for six months through teaching and conducting activities, final examination was taken for 
two contrastive groups (group of Traditional Method-T and group of Communicative Approach-C. Each group consisted of 100 participants). The students were tested in listening, reading, grammar, and vocabulary. Grammar exercises were given from the topics they studied in their syllabus (Reported Speech, Passivization, Degrees of Comparison, Synthesis and Analysis of Sentences, Sentences Errors) students were made to speak on various issues to test their spoken ability and vocabulary questions consisted of antonyms, synonyms, one word substitutes and phrasal verbs. Some of these were taken from their text and some other questions were general. Questions framed for listening and reading were same for both groups.

\subsection{Data Analysis}

Table 1: Data Analysis of the Study

\begin{tabular}{rcccccc}
\hline Activity & Max marks & C1 & C2 & C3 & C4 & AVERAGE \\
\hline R & 50 & 41.58 & 38.83 & 40.83 & 38.65 & 39.97 \\
L & 15 & 10.85 & 10.64 & 10.84 & 10.58 & 10.73 \\
S & 20 & 19.42 & 17.64 & 19.73 & 18.65 & 18.86 \\
V & 20 & 19.58 & 16.98 & 18.74 & 18.44 & 18.43 \\
G & 20 & 18.45 & 19.42 & 17.61 & 18.22 & 18.42 \\
\hline Activity & Max Marks & T1 & T2 & T3 & T4 & AVERAGE \\
\hline R & 50 & 28.94 & 32.45 & 29.04 & 22.85 & 28.32 \\
L & 15 & 8.51 & 8.22 & 9.02 & 6.47 & 8.05 \\
S & 20 & 14.01 & 11.58 & 15.76 & 10.95 & 13.07 \\
V & 20 & 16.23 & 15.64 & 12.06 & 12.84 & 14.19 \\
G & 20 & 11.21 & 10.98 & 14.01 & 13.72 & 12.48 \\
\hline
\end{tabular}

$\mathrm{R}=$ READING
$\mathrm{L}=$ LISTENING
$\mathrm{S}=$ SPEAKING
$\mathrm{V}=$ VOCABULARY
$\mathrm{G}=$ GRAMMAR

The table exhibits the performance of students in five areas of language: listening, reading, speaking, vocabulary, and grammar. According to the results it was realized that students of $\mathrm{C}$ group showed better performance than students of $\mathrm{T}$ group. So it provides evidence to believe that communicative approach will improve language ability of students and help them expand their field of thinking.

\subsection{Feed Backs}

\subsubsection{Feedback Taken By the Researcher}

At the end of the research the students were asked to describe their experiences during the experimentation. It was the unanimous opinion of the students that they found learning really a joyful activity as it was centered on them. They were bold to state that they were bored of the traditional method of teaching that insisted upon them to listen and reproduce.

\subsubsection{Feedback Taken By College Management and Other Experienced Teachers}

On the request of the researcher, the managements and other teachers of the selected colleges interacted with students to find out their opinions regarding the new approach. On hearing their comments, the researcher concluded that students were ready to welcome a new strategy in teaching that would provide them a multitude of optimum opportunities to brighten their knowledge and power to communicate in English Language. Almost all teachers except a few aged ones were in favour of the communicative approach in reading. They supported the approach because it would fetch them great contentment that students' language abilities were developed through this approach to the maximum extent and the objectives of teaching would be achieved. 


\section{Discussion}

The outcomes of the study confirm the appropriateness of the above three hypotheses.

According to the opinion of the majority of the students, Communicative Approach was successful in producing positive learning effects. Very few students, who were introvert in nature and suffered inferiority complex, were against the approach. They encountered difficulties caused by communicative activities. The other reason they said why they were reluctant to follow the approach was, many examinations were grammar based, and the scope to learn grammar and vocabulary through this approach was very thin. Although students worry about grammar-based exams, CLT does not mean only speaking and does involve grammar functioning. (Thomson, 1996) They said classroom decorum was spoiled because of noise and uncontrolled movements of students. They revealed more confidence in teachers than in their peers. After eight months, in the end examination, they showed rewarding performance. This proved that Communicative Approach would never fail to help students acquiring knowledge of grammar and vocabulary in addition to comprehension.

\section{Conclusion}

The acquisition of knowledge is possible only when the students practice language in different contexts. Frequent exposure to language usage will reduce students' anxiety to efficiently handle the language. Li (2003) asserts that judging from the feedback from students and the results of examinations, communicative approach was advantageous and favourable, and it aroused their interest in English learning and developing their learner autonomy. Communicative Approach is aimed at making the students leading lights in teaching-learning process. The advantages of this approach are noticeable. As the approach is to involve every student in the activities, its success in producing favourable results is maximum. It proves its superiority over Traditional Method through the results of students in the end examination. It is the most successful approach in inculcating in students an interest for learning English language.

\section{References}

Carnegie Corporation of New York Quarterly, 10.

Cliffor. H. Pator. (1965). Development of a Manipulation-Communication Scale. NAFSA Studies and Papers. (English Language Series, No: 10, 1965). 388

Ellis, R. (1997). Second Language Acquision. Oxford: Oxford University Press.

Hu, G. (2002). Potential Cultural Resistence to Pedagogical Imports: The Cse of Communicative Language Teaching in China. Language, Culture and Curriculum, 15(2), 93-105. http://dx.doi.org/10.1080/07908310208666636

John Dewey, J. (1916). Democracy and Education. New York: Free Press.

Knowles, M. (1970). The Modern Practice of Adult Education. New York: Association Press.

Krashen, S. (1988). The Input Hypotheses: Issues and Implications. London: Longman.

Krashen, S., \& Terrel, T. (1983). The Natural Approach: Language Acquisition in the Classroom. Oxford: Pergamon Press.

Li, L. (2003). A Study on Communicative Approach to the Teaching of English Reading. (Unpublished Thesis of master degree, Jilin University, China).

Littlewood, W. (1981). Communicative Language Teaching. New York: Cambridge University Press.

Pino-Silva, J. (1992). Extensive Reading: No Pain, No Gain. English Teaching Forum, 30(2), 48-49.

Rao, Z. (2002). Chine's Students' Perceptions of Communicative and Non-communicative Activities in EFL Classroom. System, 30(1), 85-105. http://dx.doi.org/10.1016/S0346-251X(01)00050-1

Snow, D. (1996). More Than A Narrative Speaker. Alexandra, Verginia: TESOT, Inc.

Thompson, G. (1996). Some Misconceptions about Communicative Language Teaching. ELT Journal, 50(1), 9-15. http://dx.doi.org/10.1093/elt/50.1.9

Widdowson, HG. (1978). Teaching Language as Communication. Oxford: Oxford University Press. 